\title{
Metabolism of Thiazole Acetic Acid Derivatives and the NIH Shift
}

Tне microsomal hydroxylation of para-halogen substituted anilines, acetanilides and aromatic amino-acids, with subsequent migration of the halogen function, has been termed the NIH shift ${ }^{1-4}$.

We wish to report the observation of such a metabolic process occurring in substituted thiszole acctic acids, one of which (ICI 54,450) has been shown to possess antiflammatory, analgesic and antipyretic activity (ref. 5 and following communication).

ICI $54,450,(\mathrm{I})$, whon administered orally to rats in a concentration of $50 \mathrm{mg} / \mathrm{kg}$, gave rise to two fluorescent metabolites in the ratio $2: 1$. The minor metabolite was shown by mass spectrometry to contain the moiety (II). For comparison with this metabolite the two phenols (III) and (IV) were synthesized. Thin-layer chromatographic behaviour, mass spectra abundance patterns and fluorescence spectra showed wide differences between these compounds and the minor metabolite. The compound (V) which would be formed by the NIH shift mechanism was then synthesized for comparison. This phenol was found to be identical in all spectroscopic and chromatographic respects to the minor metabolite. The identity of this metabolite was further established by inverse radioisotope dilution analysis with material metabolically dorived from ICI 54,450 labelled with ${ }^{14} \mathrm{C}$.

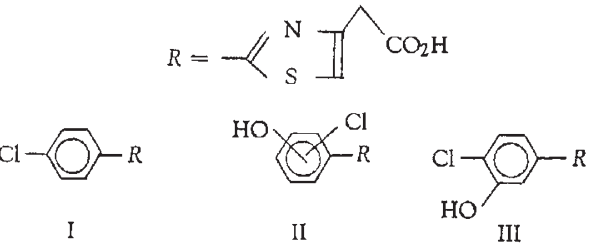

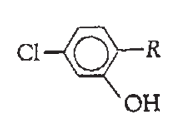

IV
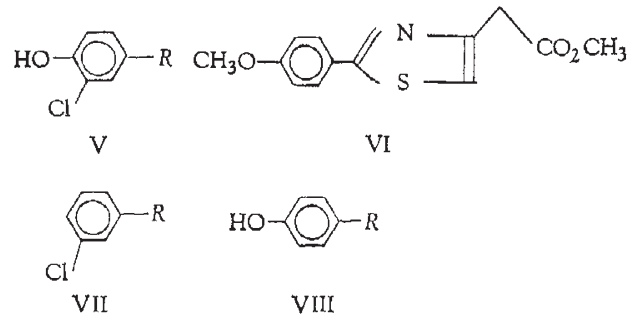

Mass spectrometry showed that the major metabolite contained a phenolic hydroxy function but no chloro substituent. The nuclear magnetic resonance spectrum of the methylation product (diazomethane) of this melabolite was consistent with the structure (VI), a symmetrical $\mathrm{A}_{2} \mathrm{~B}_{2}$ aromatic proton splitting pattern being observed.

ICI 55,100 (VII) administered to rats in the manner described for ICI 54,450 gave rise to a single metabolite. This was identical to the metabolite (V) produced by ICI 54,450. The fact that the halogen had not migrated supports the findings of Daly et al. ${ }^{4}$ that the NIH shift is restricted to para hydroxylation.

ICI 54,450 was less efficiently metabolized in dogs than in the rat. The metabolites were idontical, however, with even more of the phenol (VIII) predominating. No metabolites of ICI 54,450 were detected in monkeys and man, or in the serum of any of the spceics cxamined.

When treated with pertrifluoracetic acid in methylene chloride ${ }^{6}$, ICI 54,450 gave rise to a number of products from which it was possible to isolate the compound (V) in a yield of $10 \cdot 0$ per cent. This exemplifies an in vitro halogen migration albcit with a lower efficiency than that achieved in vivo. The phenols (III) and (IV) were not detected.

I thank Dr B. R. Webster and $\mathrm{Mr}$ W. Hepworth rospcctively for mass spcctra determination and synthetic work and Mrs G. Barnes and Mrs J. Siddall for experimental assistance.

ICI Pharmaceuticals,

D. M. Fouthes

Alderley Park, Macclesficld,

Cheshire.

Received September 26,1968

${ }^{1}$ Guroff, G., Kondo, K., and Daly, J., Biochem. Biophys. Res. Commun. $25,622(1966)$.

${ }^{2}$ Jerina, D., Daly, J., Landis, W., and Witkop, B., J. Amer. Chem. Soc., 89 3347 (1967).

${ }^{3}$ Guroff, G., Daly, J. W., Jerina, D. M., Renson, J., WitkoI, B., and Udenfriend, S., Science, 15\%, 1524 (1967)

${ }^{4}$ Daly, J. W., Guroff, G., Udenfriend, S., and Witkop, B., Biochem. Phar macol., 1 i, 31 (1968).

${ }^{5}$ Newbould, B. B., Ann. Rheum. Dis. (in the press).

${ }^{6}$ Emmons, W. D., J. Amer. Chem. Soc., 76, 3468 (1954).

\section{2-(4-chlorophenyl)thiazol-4-ylacetic Acid ('Myalex'): a New Compound with Anti-inflammatory, Analgesic and Antipyretic Activity}

The use of adjuvant-induced arthritis in rats for the testing of compounds which may be of value in the treatment of rheumatoid arthritis in $\operatorname{man}^{1}$ has resulted in the discovery, in our laboratories, of two classes of compounds with different modes of action ${ }^{2-5}$. We wish to describe brienly the properties of a third class of com. pound ${ }^{6}$ which has recently been discovered using this laboratory model.

Our initial observation was that $25 \mathrm{mg} / \mathrm{kg}$ of ethyl 4-(4-bromophenyl)thiazol-2-ylacetate, ICI 52,722 (I), given by mouth daily, reduced the inflammation associated with the development of both "primary" and "secondary" lesions in rats with adjuvant-induced arthritis.

Compound ICI 54,450, 2-(4-chlorophenyl)thiazol-4-ylacotic acid, (II), 'Myalex' (ICI), subsequently proved to be more potent and was therofore studied in more detail.<smiles>CCOC(=O)CC1CSCC(c2ccc(Br)cc2)N1</smiles>

(I)<smiles>O=C(O)Cc1csc(-c2ccc(Cl)cc2)n1</smiles>

(II)

ICI 54,450 was prepared by the reaction of $p$-chlorothiobenzamide with ethyl w-bromoacetoacetate, followed by hydrolysis of the product, ethyl 2-(4-chlorophenyl)thiazol-4-ylacetate, to tho corresponding acid. It is at colourless, crystalline solid, melting point $155^{\circ}-156^{\circ} \mathrm{C}$. It is soluble in most organic solvents but only sparingly soluble in water. Salts of varying solubility in water have been produced.

Tests for biological activity in rats, mice and guineapigs showed that ICI 54,450 is a potent anti-inflammatory agent, with analgesic and antipyretic properties. Doses within the range 2.5 to $100 \mathrm{mg} / \mathrm{kg}$ by mouth produced graded responses on adjuvant-induced arthritis in rats (developing and established), carrageenin oedema in rats ${ }^{7}$, adjuvant-indueed inflammation in mice and ultraviolet light ery thema in guinea-pigs ${ }^{8}$. The compound was also active in tests for analgesic activity, for example, the squirming syndrome in mice ${ }^{9}$. In tests for antipyretic activity, a single dose of $100 \mathrm{mg} / \mathrm{kg}$ given immediately before the injection of a bacterial pyrogen to rats com. pletely prevented the increase in body temperature. Studies in adrenalectomized arthritic rats showed that the activity of ICI 54,450 was not mediated by stimulation of 